\title{
NOVEL JOKOWI SI TUKANG KAYU KARYA GATOTKOCO SUROSO SEBAGAI MATERI AJAR APRESIASI SASTRA DI SMA: KAJIAN PSIKOLOGI SASTRA DAN NILAI KARAKTER
}

\author{
Inung Handarini, Kundharu Saddhono, Atikah Anindyarini \\ Universitas Sebelas Maret \\ Surel: ihandarini@gmail.com
}

\begin{abstract}
The purpose of this research is to describe and explain: (1) the characterization of the figures in the novel Jokowi Si Tukang Kayu by Gatotkoco Suroso, (2) the inner conflict experienced by the main figure, (3) the values of character education in the novel Jokowi Si Tukang Kayu by Gatotkoco Suroso, (4) the relevance of the values of character education as teaching materials of literature appreciation in senior high school. This research is a descriptive qualitative research which used pscychology literature. The technique of data analysis used was interactive analysis technique. The result of this research showed that the characterization of the figures in the novel Jokowi Si Tukang Kayu by Gatotkoco Suroso are described through three dimensions, dimension of psysiological, psychological, and sociological. Novel Jokowi Si Tukang Kayu also contained 18 values of character education, that are religious, honest, tolerance, discipline, hardwork, creative, independent, democratic, curiosity, spirit of nationality, love the motherland, appreciating achievement, friendly/ communicative, love and peace, loving to read, care for the environtment, social care, and responsibility. Novel Jokowi Si Tukang Kayu is relevant to be used as teaching materials of literature appreciation in senior high school at class XII.
\end{abstract}

Keywords: psychological literature, figure, innerconflict, Jokowi Si Tukang Kayu

\begin{abstract}
Abstrak:Tujuan penelitian ini adalah untuk menjelaskan: (1) perwatakan tokoh dalam novel Jokowi Si Tukang Kayu karya Gatotkoco Suroso, (2) konflik batin yang dialami tokoh utama, (3) nilai-nilai pendidikan karakter dalam novel Jokowi Si Tukang Kayu, dan (4) relevansi novel Jokowi Si Tukang Kayu sebagai materi ajar apresiasi sastra di SMA. Penelitian ini merupakan penelitian deskriptif kualitatif dengan pendekatan psikologi sastra. Analisis data menggunakan teknik analisis interaktif. Hasil peneitian ini menunjukkan bahwa perwatakan tokoh dalam novel Jokowi Si Tukang Kayu digambarkan melalui tiga dimensi, yaitu dimensi fisiologis, psikologis, dan sosiologis. Novel Jokowi Si Tukang Kayu juga mengandung 18 nilai pendidikan karakter, yakni nilai religius, jujur, toleransi, disiplin, kerja keras, kreatif, mandiri, demokratis, rasa ingin tahu, semangat kebangsaan, cinta tanah air, menghargai prestasi, bersahabat/ komunikatif, cinta damai, gemar membaca, peduli lingkungan, peduli sosial, dan tanggung jawab. Novel Jokowi Si Tukang Kayu relevan untuk dijadikan sebagai materi ajar apresiasi sastra di SMA kelas XII.
\end{abstract}

Kata Kunci: psikologi sastra, watak, konflik batin, nilai pendidikan karakter.

\section{PENDAHULUAN}

Karya sastra (novel, cerpen, dan puisi) adalah karya imajinatif, fiksional, dan ungkapan ekspresi pengarang (Susanto, 2012: 32). Karya sastra merupakan produk dari suatu kejiwaan dan pemikiran pengarang yang berada pada situasi 
setengah sadar (subconsious). Setelah jelas, baru dituangkan ke dalam bentuk secara sadar (conscious). Antara kesadaran dan ketidaksadaran, selalu mewarnai dalam proses imajinasi pengarang. Oleh karena itu, karya sastra tidak terlepas dari psikologi (Endraswara, 2008: 96).

Novel adalah karya fiksi prosa (karangan yang berasal dari khayalan atau rekaan penulis) secara tertulis, biasanya dalam bentuk cerita. Novel lebih panjang dan lebih kompleks dibandingkan dengan cerpen dan tidak dibatasi keterbatasan struktural. Isi novel mengisahkan problematika kehidupan seseorang atau beberapa tokoh secara utuh (Syarifuddin, dkk, 2014: 191).

Tokoh adalah pelaku atau pemeran yang memerankan cerita (Sehandi, 2014: 55). Membahas mengenai tokoh tentu tidak dapat terlepas dari penokohan. Penokohan adalah pelukisan gambaran yang jelas tentang seseorang yang ditampilkan dalam sebuah cerita (Nurgiyantoro, 2005: 165).

Konflik batin adalah konflik yang terjadi di dalam hati, jiwa seorang tokoh atau tokoh-tokoh cerita. Jadi konflik batin merupakan konflik yang dialami manusia dengan dirinya sendiri atau permasalahan interen seorang manusia, misalnya hal tersebut terjadi karena akibat adanya pertentangan antara dua keinginan, keyakinan, pilihan yang berbeda, harapan-harapan atau masalahmasalah lainnya. Tingkat kompleksitas konflik yang ditampilkan dalam sebuah karya fiksi dalam banyak hal, menentukan kualitas, intensitas, dan ketertarikan karya tersebut (Nurgiyantoro, 2009:119).

Psikologi sastra merupakan gabungan antara ilmu sastra dan psikologi. Secara definitif, psikologi sastra adalah analisis terhadap karya sastra dengan mempertimbangkan relevansi aspek-aspek psikologis atau kejiwaan yang terkandung di dalamnya. Psikologi sastra lebih banyak berkaitan dengan tokoh dan penokohan, dengan tiga wilayah analisis, yakni psikologi pengarang, psikologi tokoh-tokoh dalam karya sastra, dan psikologi pembaca sastra (Sehandi, 2014: 46).

Freud membagi struktur kepribadian manusia menjadi tiga macam, yakni (1) id, (2) ego, (3) superego. Idadalah struktur paling mendasar dari kepribadian 
manusia, seluruhnya tidak disadari dan bekerja menurut prinsip kesenangan, tujuannya pemenuhan kepuasan yang segara. Ego berkembang dari id, struktur kepribadian yang mengontrol kesadaran dan mengambil keputusan atas perilaku manusia. Superego berkembang dari ego saat manusia mengerti nilai baik dan buruk serta nilai moral. Superego merefleksikan nilai-nilai sosial dan menyadarkan individu atas tuntutan moral. Apabila terjadi pelanggaran nilai, superego menghukum ego dengan menimbulkan rasa salah. Ego selalu menghadapi ketegangan antara tuntutan Iddan superego. Apabila tuntutan ini tidak berhasil di atasi dengan baik, maka ego terancam dan muncullah kecemasan (anxiety). Dalam rangka menyelamatkan diri dari ancaman, ego melakukan reaksi defensive atau pertahanan diri (Freud dalam Minderop, 2010: 20-22).

Novel Jokowi Si Tukang Кауи merupakan sebuah novel biografi karya Gatotkoco Suroso yang diterbitkan pada tahun 2012. Banyak nilai pendidikan karakter yang terdapat dalam novel ini, diantaranya adalah nilai religius, kerja keras, kreatif, mandiri, bersahabat/ komunikatif, cinta damai, gemar membaca, peduli lingkungan, peduli sosial, dan tanggung jawab. Novel Jokowi Si Tukang Kayu adalah novel yang menceritakan kisah perjuangan cinta dan cita-cita Joko Widodo dari kecil hingga menjadi Walikota Surakarta. Novel ini menyajikan berbagai konflik batin yang dialami tokoh utama, Joko Widodo. Dengan demikian, novel ini menjadi berbobot dan bermutu, sehingga memberikan manfaat bagi pembacanya.

Nilai-nilai pendidikan karakter novel Jokowi Si Tukang Kayudapat direlevansikan dalam materi ajar apresiasi sastra di SMA. Khususnya dalam Kurikulum 2013 edisi 2016 pada kelas XII yakni pada kompetensi dasar (KD) antara lain: KD 3.14 mengidentifikasi nilai-nilai yang terdapat dalam sebuah buku pengayaan (nonfiksi) dan satu buku drama (fiksi), dan KD 4.14 Menulis refleksi tentang nilai-nilai yang terkandung dalam sebuah buku pengayaan (nonfiksi) dan satu buku drama (fiksi).

Peneliti memilih novel Jokowi Si Tukang Kayu karya Gatotkoco Suroso untuk memahami perwatakan tokoh-tokoh, konflik batin yang dialami tokoh 
utama, nilai-nilai pendidikan karakter, dan relevansi novel sebagai materi ajar apresiasi sastra di SMA.

\section{METODE PENELITIAN}

Penelitian ini dilakukan selama enam bulan, yakni pada bulan Februari 2018 - Juli 2018. Pendekatan yang digunakan dalam penelitian ini berupa penelitian kualitatif dengan jenis penelitian deskriptif. Data dikumpulkan dengan cara mengkaji dokumen berupa novel yang berjudul Jokowi Si Tukang Kayu karya Gatotkoco Suroso yang diterbitkan oleh penerbit Ufuk Fiction Jakarta pada tahun 2012 dengan tebal 246 halaman, yang terdiri dari 24 bab. Data divalidasi menggunakan triangulasi teori dan triangulasi sumber. Teknik analisis data dalam penelitian ini menggunakan teknik analisis interaktif yang meliputi empat komponen, yaitu (1) pengumpulan data, (2) reduksi data, (3) penyajian data (display data), (4) penarikan simpulan (verifikasi).

\section{HASIL PENELITIAN DAN PEMBAHASAN}

\section{Perwatakan Para Tokoh dalam Novel}

Tokoh adalah pelaku atau pemeran yang memerankan cerita (Sehandi, 2014: 55). Membahas mengenai tokoh tentu tidak dapat terlepas dari penokohan. Penokohan adalah pelukisan gambaran yang jelas tentang seseorang yang ditampilkan dalam sebuah cerita (Nurgiyantoro, 2005: 165).

Setiap tokoh memiliki sifat atau watak yang berbeda-beda. Dalam menggambarkan watak tokoh, Waluyo (2011: 21) mengatakan bahwa pengarang mempertimbangkan tiga dimensi watak, yaitu dimensi psikis (kejiwaan), dimensi fisik (jasmaniah), dan dimensi sosiologis (latar belakang kekayaan, pangkat, dan jabatan).

Watak dari segi psikis merupakan faktor utama yang terpenting dalam penggambaran watak atau temperamen tokoh, apakah tokoh itu baik hati, penyabar, murah hati, dermawan, pemaaf, ataukah ia pemberang, sombong, pemarah, berhati jahat, pendengki, pendendam, tidak memiliki rasa belas kasih, 
dan licik.Watak dari segi fisiologis atau keadaan fisik, dapat dikaitkan dengan umur, ciri fisik, penyakit, keadaan diri, dan sebagainya. Watak dari segi sosiologis melukiskan suku, jenis kelamin, kekayaan, kelas sosial, pangkat/ kedudukan, dan profesi atau pekerjaan.

Analisis perwatakan 52 tokoh dalam novel Jokowi Si Tukang Kayu dilakukan berdasarkan dimensi fisiologis, psikologis dan sosiologis. Watak para tokoh digambarkan melalui ketiga dimensi tersebut, namun tidak semua tokoh ditampilkan menggunakan ketiga dimensi itu secara lengkap.

Dari hasil analisis diperoleh watak tokoh. Secara fisiologis tokoh Joko Widodo digambarkan sebagai pemuda yang kurus atau ceking, tinggi, berambut gondrong, dan berkulit gelap. Secara psikologis, Joko Widodo digambarkan sebagai seorang yang menyukai musik rock, memiliki belas kasih, tidak bisa diam, keras kepala, percaya diri, pintar, kreatif, mandiri, dan bertanggungjawab. Dari segi sosiologis, Joko Widodo adalah seorang anak yang dilahirkan di bantaran Kali Pepe. Ia adalah anak dari penjual kayu dan bambu.

Tokoh Notomiharjo adalah ayah dari Joko Widodo. Secara fisiologis Notomiharjo digambarkan sebagai seorang yang tangguh. Secara psikologis, Notomiharjo adalah orang yang memiliki kemandirian yang kuat, pekerja keras, mengalah, disiplin, pengertian dan jujur. Ditinjau dari dimensi sosiologis, Notomiharjo adalah seorang pedagang kayu dan bambu, satgas pada salah satu partai politik, dan pekerja serabutan yakni sopir.

Tokoh Sujiatmi adalah ibu dari Joko Widodo. Secara fisiologis Sujiatmi digambarkan sebagai sosok yang berdagu tirus dan memiliki bibir luwes ndhemes. Secara psikologis, Sujiatmi digambarkan sebagai sosok yang pengertian, disiplin, mengalah dan membantu suaminya dalam menjalankan perekonomian keluarga. Secara sosiologis, Sujiatmi merupakan pedagang dan pekerja serabutan.

Iit Sriyantini adalah adik dari Joko Widodo. Secara fisiologis, Iit digambarkan sebagai sosok yang cantik. Secara psikologis, Iit digambarkan sebagai sosok yang manja, iseng, dan senang menggoda Joko Widodo. Secara sosiologis, tentunya Iit sama dengan Joko Widodo yakni anak seorang penjual kayu dan bambu. 
Tokoh Hidayati adalah adik dari Joko Widodo. Secara fisiologis, Yati digambarkan sebagai seorang yang memiliki dagu lancip, tirus, bibir selalu senyum, bibir dan dagu luwes ndhemes. Secara psikologis, Yati digambarkan sebagai pribadi yang manja dan iseng. Secara sosiologis, tentunya Yati sama dengan Joko Widodo yakni anak seorang penjual kayu dan bambu dan merupakan adik Joko Widodo.

Tokoh Titik Ritawati adalah adik dari Joko Widodo. Ditinjau dari dimensi psikologis, Titik merupakan sosok yang manja dan iseng. Ditinjau dari segi sosiologis, Yati merupakan anak seorang penjual kayu dan bambu, serta merupakan adik Joko Widodo yang paling kecil.

Tokoh Pakdhe Miyono adalah paman Joko Widodo. Secara psikologis, Pakdhe Miyono memiliki sifat yang baik hati, karena mau menampung Joko Widodo sekeluarga saat mengalami penggusuran dan tak memiliki rumah. Ditinjau dari dimensi sosiologis, Pakdhe Miyono merupakan kakak dari Ibu Joko Widodo,

Tokoh Mbah Harjo adalah tetangga sebelah rumah Joko Widodo. Secara psikologis, Mbah Harjo digambarkan sebagai sosok yang pandai berpetuah dan sangat dermawan. Ditinjau dari segi sosiologis, Mbah Harjo merupakan tetangga dekat Joko Widodo.

Tokoh Nindy Dewi Lestari merupakan teman sekelas Joko Widodo semasa kelas II SMP. Secara fisiologis, Dewi digambarkan sebagai sosok yang cantik, gemulai dan memiliki kebiasaan mengepang dua rambutnya. Secara psikologis, Dewi digambarkan sebagai sosok yang pandai dan rajin belajar. Secara sosiologis, Dewi digambarkan sebagai anak kepala sekolah.

Tokoh Rudi merupakan teman dekat Joko Widodo semasa duduk di bangku kelas III SMP. Secara fisiologis, Rudi digambarkan dengan sosok yang hitam manis, berambut klimis, memiliki jam mahal dipergelangan tangan. Secara psikologis, Rudi digambarkan sebagai sosok yang tidak memilih-milih dalam bergaul dengan temannya. Secara sosiologis, Rudi adalah anak dari mandor tebu, bertetangga dengan Giman dan menjadi teman sekelas Joko Widodo. 
Tokoh Iriana adalah teman SMA adik JokoWidodo, Iit Sriyantini. Secara fisiologis, Iriana merupakan seseorang yang dikagumi dan disukai Joko Widodo. Iriana digambarkan sebagai seorang yang cantik, rupawan, manis, dan memiliki jari-jari kaki yang putih bersih terawat. Secara psikologis, Iriana digambarkan sebagai sosok yang ceria dan setia. Secara sosiologis, Iriana merupakan teman Iit semasa SMA.

Tokoh Pak Darno adalah seseorang yang berpura-pura ingin membeli mebel Joko Widodo namun ternyata adalah seorang penipu. Ditinjau dari segi fisiologis, Pak Darno digambarkan sebagai sosok laki-laki paruh baya dan bersahaja. Ditinjau dari segi psikologis, Pak Darno digambarkan sebagai sosok yang menipu usaha mebel Joko Widodo. Ditinjau dari segi sosiologis, Pak Darno merupakan lelaki kaya.

\section{Konflik Batin Tokoh Utama}

Pada dasarnya psikologi sastra memberikan perhatian pada masalah kejiwaan para tokoh fiksional yang terkandung dalam karya sastra (Ratna, 2003: 343). Pendekatan psikologi adalah pendekatan bahwa karya sastra selalu saja membahas tentang peristiwa kehidupan manusia (Semi, 2012: 96).

Dalam sebuah cerita, khususnya novel tentu terdapat permasalahan yang disebut konflik. Permasalahan kehidupan yang dialami oleh tokoh dalam novel sangat berpengaruh pada perilaku tokoh tersebut. Perilaku yang melekat pada tokoh dapat dikaji dengan pendekatan psikologi. Psikologi memandang perilaku manusia (human behavior) sebagai reaksi yang dapat bersifat sederhana maupun bersifat kompleks (Djojosuroto, 2006: 9).

Di dalam ilmu psikologi, terdapat teori yang mengusulkan bagaimana mempelajari tentang aspek kejiwaan maupun penokohan dalam karya sastra. Teori ini digunakan untuk mempelajari tentang kesadaran dan ketidaksadaran pada manusia. Teori psikologi tersebut diperkenalkan oleh Sigmund Freud. Menurutnya, semua gejala mental bersifat tak sadar yang tertutup oleh alam kesadaran (Schellenberg dalam Ratna, 2009:62). 
Psikoanalisis adalah teori sastra yang mengkaji unsur kejiwaan para tokoh di dalam karya sastra. Sigmund Freud menjelaskan bahwa manusia lebih banyak dikondisikan oleh alam bawah sadar yang sering disebutnya sebagai "metafora gunung es". Wilayah alam bawah sadar ini tidak disadari oleh manusia, tetapi menentukan hampir keseluruhan kehidupannya. Pencetus sekaligus tokoh kunci teori psikoanalisis adalah Sigmund Freud (1856-1939), seorang ahli psikologi yang kontroversial dan sangat terkenal. Sigmund Freud adalah ahli neurologi (ilmu syaraf) dan neuropsikiatri sekaligus penemu teori psikoanalisis. Sigmund Freud lahir di Austria, 6 Mei 1856, meninggal dunia di London, 23 September 1939 (Sehandi, 2014: 119-120).

Freud membagi struktur kepribadian manusia menjadi tiga macam, yakni (1) id, (2) ego, (3) superego. Idadalah struktur paling mendasar dari kepribadian manusia, seluruhnya tidak disadari dan bekerja menurut prinsip kesenangan, tujuannya pemenuhan kepuasan yang segara. Ego berkembang dari id, struktur kepribadian yang mengontrol kesadaran dan mengambil keputusan atas perilaku manusia. Superego berkembang dari ego saat manusia mengerti nilai baik dan buruk serta nilai moral. Superego merefleksikan nilai-nilai sosial dan menyadarkan individu atas tuntutan moral. Apabila terjadi pelanggaran nilai, superegomenghukum ego dengan menimbulkan rasa salah. Ego selalu menghadapi ketegangan antara tuntutan Iddan superego. Apabila tuntutan ini tidak berhasil di atasi dengan baik, maka ego terancam dan muncullah kecemasan (anxiety). Dalam rangka menyelamatkan diri dari ancaman, ego melakukan reaksi defensive atau pertahanan diri.

Kejiwaan tokoh dalam novel Jokowi Si Tukang Kayu merucut pada fenomena $i d$, ego dan super ego yang dialami yokoh utama, yakni Joko Widodo. Tokoh Joko Widodo adalah tkoh yang baik, cerdas, dan mampu menyelesaikan masalah yang ia hadapi. Id, ego, dan superego dalam diri Joko Widodo selalu berjalan beriringan. Beberapa konflik batin yang dialami Joko Widodo adalah sebagai berikut. 
Konflik batin yang dialami Joko Widodo adalah konflik batin dalam dirinya saat tidak diterima dalam pendaftaran SMA yang ia inginkan.Iddalam diri Jokowi yang menginginkan untuk dapat melanjutkan jenjang SMA, yakni di SMAN 1 Surakarta. Ego melihat realita bahwa DANEM (Daftar Nilai Ebtanas Murni) yang dimiliki Jokowi kurang dari batas ketetapan pendaftaran di SMAN 1 Surakarta membuatnya tidak diterima di SMA tersebut. Meskipun merasa sedih dan kecewa ia berusaha bangkit. Super Ego mampu meredam dan menyikapi kekecewaan yang dialaminya, sehingga Jokowi memutuskan untuk mendaftarkan diri di SMAN 6 Surakarta dengan harapan bahwa di sana ia termasuk ke dalam siswa yang memiliki NEM tinggi.

Konflik batin dalam diri Jokowi yang ingin memiliki kekasih. Iddalam diri Jokowi menginginkan bahwa dirinya semasa SMA ingin memiliki kekasih. Ego melihat realita bahwa teman-teman sebaya Jokowi yang sudah memiliki kekasih pada sat itu. Namun, dengan mengingat bahwa Jokowi masih duduk di bangku SMA dan masih mendapat uang saku dari orangtuanya, serta mengingat nasihat yang diberikan oleh Bapak, Ibu, Pak Guru, Mbah Harjo, dan Pakdhe Miyono. Jokowi merasa sadar bahwa bermodalkan pintar saja menurutnya tidak cukup untuk mendekati perempuan. Akhirnya, Jokowi memutuskan untuk menahan diri dalam mendekati perempuan. Super Ego dalam diri Jokowi menimbang-nimbang dan memutuskan bahwa keputusannya untuk menahan diri dalam mencari kekasih adalah keputusan yang tepat.

Konflik batin dalam diri Jokowi ketika Jokowi ingin berkuliah.Iddalam diri Jokowi yang menginginkan untuk melanjutkan ke Perguruan Tinggi setelah lulus dari SMA. Ego melihat realita bahwa orangtuanya yang bekerja serabutan dengan hasil yang pas-pasan membuat Jokowi mengurungkan niatnya dan bertekad untuk membantu orangtuanya mblandong kayu, mencari dan menjual kayu. Namun, sang ayah menyuruh Jokowi untuk terus melanjutkan ke jenjang Perguruan Tinggi bagaimanapun caranya. Superego, akhirnya Jokowi menerima permintaan ayahnya yang sejalan dengan keinginannya, sehingga ia bertekad untuk 
melanjutkan ke jenjang Perguruan Tinggi dengan sungguh-sungguh dan tidak ingin mengecewakan kedua orangtuanya.

Konflik batin dalam diri Jokowi ketika naksir dengan Iriana.Iddalam diri Jokowi yang berkenalan dengan iriana kemudian jatuh hati pada Iriana, sehingga ingin membuatnya menjadi kekasih. Ego melihat realita bahwa selama Jokowi dan Iriana saling mengenal, keduanya merasa saling mendukung dan tidak mengganggu prestasi masing-masing selama di sekolah, serta latar belakang keluarga yang sudah saling mengenal satu sama lain. Super Ego dalam diri Jokowi memustuskan bahwa dirinya akan menyatakan cintanya kepada Iriana.

Konflik batin ketika Jokowi bekerja di pabrik kertas Aceh, dan ingin kembali ke Solo lagi untuk memulai usaha baru.Iddalam diri Jokowi yang ingin kembali ke Solo untuk memulai usaha baru. Namun, sang istri meragukannya. Ego menimbang-nimbang denganmelihat realita bahwa di tempat perantauannya yakni Aceh yang berada di tengah hutan, maka bukan tidak mungkin akan terhindar dari ancaman binatang buas dan realita bahwa Pakdhe Miyono membutuhkan tenaga Jokowi untuk membantu usahanya. Super Ego dalam diri Jokowi memutuskan tekadnya untuk tetap kembai ke Surakarta, meskipun diragukan oleh sang istri. Dengan usahanya untuk meyakinkan sang Istri, maka mereka akhirnya kembali ke Surakarta.

Konflik batin ketika Jokowi mengalami kerugian, akibat penipuan yang dilakukan oleh Pak Darno.Iddalam diri Jokowi merasa sedih dan terpuruk akibat penipuan yang dilakukan oleh Pak Darno. Ego dalam diri Jokowi menimbang dan mengingat nasihat yang diberikan oleh ibu Jokowi agar tidak cengeng menghadapi permasalahan. Super Ego dalam diri Jokowi memutuskan untuk bangkit dari keterpurukan akibat penipuan yang telah dialaminya dan mengakibatkan kegiatan produksi berhenti selama delapan bulan. Berdasarkan keputusannya, usaha Jokowi akhirnya berjalan kembali.

Konflik batin dalam diri Jokowi yang merasa ingin mencalonkan diri sebagai Walikota Surakarta. Iddalam diri Jokowi yang menginginkan dirinya untuk mencalonkan diri sebagai Walikota Surakarta, karena ia merasa tidak setuju 
dengan birokrasi pada saat itu. Ego dalam diri Jokowi yang melihat fakta bahwa ia tidak puas dengan birokrasi yang berjalan pada saat itu, sehingga ia ingin membuat perubahan. Berbekal nasihat dan persetujuan dari istri, ibu dan anaknya Jokowi merasa mantap mencalonkan diri sebagai walikota Surakarta. Super Ego memutuskan bahwa Jokowi mantap mencalonkan diri sebagai walikota Surakarta.

Beberapa konflik batin yang dialami tokoh utama dapat diatasi dengan baik, karena antara id, ego, dan superego berjalan secara beriringan dan lancar. Hal ini sesuai dengan pendapat Zubaida (2013: 301) yang menyebutkan jika id, ego, superego dalam diri manusia tidak berjalan beriringan maka seorang individu akan mengalami ketakutan, kegeliahan, kemarahan dan lainnya. Tetapi jika id, ego, dan superego mampu berjalan dengan seimbang maka akan tercipta manusia yang wajar. Hal-hal yang disebutkan Zubaida mengarah pada id, ego dan superego Joko Widodo yang selalu berdampingan sehingga ia dapat mengatasi masalah yang ia hadapi.

\section{Nilai Pendidikan Karakter}

Kata "karakter" diartikan sebagai tabiat, sifat-sifat kejiwaan, akhlak atau budi pekerti yang membedakan seseorang dengan yang lain, dan watak (Kamus Besar Bahasa Indonesia dalam Wibowo, 2013: 11-12). Pendidikan karakter adalah pendidikan yang menanamkan dan mengembangkan karakter-karakter luhur kepada anak didik, sehingga mereka memiliki karakter luhur itu, menerapkan dan mempraktikkan dalam kehidupannya, entah dalam keluarga, sebagai anggota masyarakat dan warga negara (Kemdiknas, 2010: 8).

Mengacu pada 18 nilai pendidikan karakter yang dicetuskan oleh Kemdiknas. Pembahasan nilai pendidikan karakter yang terkandung dalam novel Jokowi Si Tukang Кауи karya Gatotkoco Suroso meliputi 18 nilai pendidikan karakter, yakni nilai religius, jujur, toleransi, disiplin, kerja keras, kreatif, mandiri, demokratis, rasa ingin tahu, semangat kebangsaan, cinta tanah air, menghargai prestasi, bersahabat/ komunikatif, cinta damai, gemar membaca, peduli lingkungan, peduli sosial, dan tanggung jawab. 
Nilai religius yang dapat dipetik dari novel Jokowi Si Tukang Kayu adalah jika seseorang ingin mendapatkan sesuatu harus berusaha dan berdoa, dalam hidup harus bersyukur, sebelum melakukan aktivitas tertentu hendaknya memulai dengan doa, dan selalu mengucap salam.

Nilai jujur yang dapat dipetik dari novel Jokowi Si Tukang Kayu adalah bahwa dalam berkata hendaknya seseorang selalu jujur agar dapat dipercaya.Nilai toleransi yang dapat dipetik dari novel Jokowi Si Tukang Kayu adalah dalam menjalin hubungan dengan sesama manusia harus menghargai orang lain, menghormati perbedaan, dan menjaga kerukunan.Nilai disiplin yang dapat dipetik dari novel Jokowi Si Tukang Kayu adalah harus disiplin dalam berbagai hal salah satunya adalah dalam belajar, dan tidak menunda-nunda pekerjaan.

Nilai kerja keras yang dapat dipetik dari novel Jokowi Si Tukang Kayu adalah selalu berusaha dalam mendapatkan sesuatu.Nilai kreatif yang dapat dipetik dari novel Jokowi Si Tukang Kayu adalah dalam hidup seseorang harus memiliki sifat kreatif agar dapat menghasilkan ide atau sesuatu yang bermanfaat.Nilai mandiri yang dapat dipetik dari novel Jokowi Si Tukang Kayu adalah jangan selalu bergantung pada oranglain, harus memiliki sifat mandiri. Nilai demokratis yang dapat dipetik dari novel Jokowi Si Tukang Кауи adalah bahwa kita harus sadar bahwa pemerintahan itu dari rakyat, oleh rakyat, dan untuk rakyat.

Nilai rasa ingin tahu yang dapat dipetik dari Jokowi Si Tukang Kayu adalah Jokowi tetap melanjutkan sekolahnya dan menimba ilmu.Nilai semangat kebangsaan yang dapat dipetik dari Jokowi Si Tukang Kayu adalah Jokowi ingin mencalonkan diri menjadi Walikota Surakarta untuk mengubah sistem yang ada.Nilai cinta tanah air yang dapat dipetik dari novel Jokowi Si Tukang Kayu adalah selalu mencintai tanah air, Indonesia. Salah satu caranya adalah menghargai jasa pahlawan.

Nilai menghargai prestasi yang dapat dipetik dari novel Jokowi Si Tukang Kayu adalah dalam hal prestasi kita harus menghargai prestasi diri sendiri maupun oranglain, tidak boleh mengolok-olok, tidak boleh iri maupun sombong dengan prestasi diri sendiri maupun orang lain. 
Nilai bersahabat/ komunikatif yang dapat dipetik dari novel Jokowi Si Tukang Кауи adalah dalam hidup bermasyarakat hendaknya kita dapat bergaul dengan siapapun dan dapat menempatkan diri dimanapun berada.Nilai cinta damai yang dapat dipetik dari novel Jokowi Si Tukang Кayu adalah kita tidak dapat hidup tanpa bantuan orang lain, kita harus tahu diri, tidak boleh merasa paling kuat, paling hebat, dan paling berguna.

Nilai gemar membaca yang dapat dipetik dari novel Jokowi Si Tukang Kayu adalah dengan banyak membaca maka pengetahuan kita akan bertambah.Nilai peduli lingkungan yang dapat dipetik dari novel Jokowi Si Tukang Kayu adalah mengabdi kepada masyarakat, dan membuat pemberdayaan pemuda-pemuda desa.Nilai peduli sosial yang dapat dipetik dari novel Jokowi Si Tukang Kayu adalah saling membantu kepada yang membutuhkan, dan membantu orangtua.

Nilai tanggung jawab yang dapat dipetik dari novel Jokowi Si Tukang Kayu adalah dalam menjalankan setiap hal harus disertai rasa tanggung jawab, bisa menjaga adik, sebagai anak pertama harus dapat menggantikan peran ayah, dan dapat menjadi panutan bagi adik-adik.

\section{Relevansi Novel Jokowi Si Tukang Kayu sebagai Materi Ajar Apresiasi Sastra di SMA}

Menurut Dra. Sri Handayani kelebihan dari novel Jokowi Si Tukang Kayu terletak pada kandungan nilai-nilai pendidikan karakter yang termuat didalamnya, sehingga dapat dijadikan teladan bagi pembaca, khususnya siswa. Berdasarkan hal tersebut, novel ini cocok dijadikan sebagai materi ajar di SMA kelas XII. Menurut Drs. Agus Setiyono kelebihan dari novel Jokowi Si Tukang Kayu terletak pada nilai pendidikan karakter dan kebudayaan Jawa yang ditonjolkan sebagai muatan lokal dalam novel, sehingga dapat dicontoh siswa, khususnya siswa kelas XII SMA.

Adanya kompetensi dasar tentang apresiasi sastra pada Kurikulum 2013 edisi revisi 2016 pada mata pelajaran Bahasa Indonesia kelas XII tentang mengidentifikasi nilai-nilai yang terdapat dalam sebuah buku, membuat novel 
Jokowi Si Tukang Kayu karya Gatotkoco Suroso layak untuk dijadikan sebagai materi ajar apresiasi sastra di SMA. Selain itu, novel Jokowi Si Tukang Kayu memiliki banyak nilai-nilai pendidikan karakter yang dapat diteladani pembaca, khususnya siswa.

\section{SIMPULAN}

Perwatakan tokoh-tokoh dalam novel Jokowi Si Tukang Kayu karya Gatotkoco Suroso dianalisis berdasarkan tiga dimensi watak, yaitu dimensi fisiologis, dimensi psikologis, dan dimensi sosiologis. Watak para tokoh digambarkan melalui ketiga dimensi tersebut, namun tidak semua tokoh ditampilkan menggunakan ketiga dimensi itu secara lengkap.

Tokoh utama dalam novel Jokowi Si Tukang Kayu adalah Joko Widodo. Analisis konflik batin tokoh utama dalam novel Jokowi Si Tukang Kayu karya Gatotkoco Suroso didasarkan pada teori kepribadian psikoanalisis Sigmund Freud yang dipengaruhi oleh tiga struktur kepribadian yaitu Id, Ego, dan Super Ego. Ketiganya saling berkaitan, maka jika ada pertentangan di antara ketiga unsur tersebut akan menimbulkan konflik batin dalam kejiwaan manusia. Di dalam novel Jokowi Si Tukang Kayu karya Gatotkoco Suroso, konflik batin yang dialami sebagian besar berasal dari dorongan internal tokoh. Konflik batin yang dialami Joko Widodo adalah konflik batin dalam dirinya saat tidak diterima dalam pendaftaran SMA favorit yang ia inginkan. Konflik batin dalam diri Jokowi yang ingin memiliki kekasih. Konflik batin dalam diri Jokowi ketika Jokowi ingin berkuliah. Konflik batin dalam diri Jokowi ketika naksir dengan Iriana. Konflik batin ketika Jokowi bekerja di pabrik kertas Aceh dan ingin kembali ke Solo lagi untuk memulai usaha baru.

Konflik batin ketika Jokowi mengalami kerugian, akibat penipuan yang dilakukan oleh Pak Darno. Konflik batin dalam diri Jokowi yang merasa ingin mencalonkan diri sebagai Walikota Surakarta.Terdapat 18 nilai pendidikan karakter dalam novel Jokowi Si Tukang Kayu karya Gatotkoco Suroso meliputi nilai religius, jujur, toleransi, disiplin, kerja keras, kreatif, mandiri, demokratis, 
rasa ingin tahu, semangat kebangsaan, cinta tanah air, menghargai prestasi, bersahabat/ komunikatif, cinta damai, gemar membaca, peduli lingkungan, peduli sosial, dan tanggung jawab.

Dari hasil analisis dan wawancara dengan informan dapat diketahui bahwa novel Jokowi Si Tukang Kayu karya Gatotkoco Suroso mengandung banyak nilai pendidikan karakter. Nilai-nilai pendidikan karakter tersebut dapat diteladani oleh pembaca, khususnya siswa SMA, sehingga berpengaruh pada kepribadian dan karakternya. Informan berpendapat bahwa novel Jokowi Si Tukang Kayu relevan untuk dijadikan materi ajar siswa SMA, khususnya pada SMA kelas XII dengan Kompetensi Dasar antara lain: KD 3.14 mengidentifikasi nilai-nilai yang terdapat dalam sebuah buku pengayaan (nonfiksi) dan satu buku drama (fiksi), dan KD 4.14 Menulis refleksi tentang nilai-nilai yang terkandung dalam sebuah buku pengayaan (nonfiksi) dan satu buku drama (fiksi).

\section{DAFTAR PUSTAKA}

Djojosuroto, Kinayati. (2006). Analisis Teks Sastra dan Pengajarannya. Yogyakarta: Pustaka.

Endraswara, Suwardi. (2008). Metode Penelitian Psikologi Sastra: Teori, Langkah, dan Penerapannya. Yogyakarta: MedPress

Kementrian Pendidikan Nasional. (2010). Pengembangan Pendidikan Budaya dan

Karakter Bangsa. Bahan Pelatihan Penguatan Metodologi Pembelajaran Berdasarkan Nilai-nilai Budaya Untuk Membentuk Daya Saing dan Karakter Bangsa. Jakarta: Kementrian Pendidikan Nasional.

Minderop, Albertine. (2010). Psikologi Sastra: Karya Sastra, Metode, Teori, dan

Contoh Kasus. Jakarta: Yayasan Pustaka Obor Indonesia

Nurgiyantoro, Burhan. (2005). Teori Pengkajian Fiksi. Yogyakarta: Gadjah Mada University Press . (2009). Teori Pengkajian Fiksi. Yogyakarta: Gadjah Mada University

Press 
Ratna, Nyoman Kutha, S.U. (2009). Teori, Metode, dan Teknik Penelitian Sastra. Rev. ed. Yogyakarta: Pustaka Pelajar

Sehandi, Yohanes. (2014). Mengenal 25 Teori Sastra. Yogyakarta: Ombak Semi, Atar. (1993). Anatomi Sastra. Padang: Angkasa Raya Padang Susanto, Dwi. (2012). Pengantar Teori Sastra. Jakarta: PT. Buku Seru Syarifuddin, dkk. (2014). 3 in 1 Solusi Cerdas BBM SMA/MA Kelas 1,2, dan 3.Jakarta: Bintang Wahyu

Waluyo, Herman J. (2011). Pengkajian dan Apresiasi Prosa Fiksi. Surakarta: UNS Press

Wibowo, Agus. (2013). Pendidikan Karakter Berbasis Sastra. Yogyakarta: Pustaka Pelajar

Zubaida, R. A., Swandono, \& Waluyo, B. (2014) Analisis Tokoh dan Nilai Pendidikan dalam Novel Gajahmada Karya Langit Kresna Hariadi (Tinjauan Psikologi Sastra).vBASASTRA.1 (2): 301-302. 